\title{
In vitro propagation of Ananas comosus var. ananassoides (Baker) Coppens \& F. Leal (Bromeliaceae)
}

\section{Propagação in vitro de Ananas comosus var. ananassoides (Baker) Coppens \& F. Leal (Bromeliaceae)}

\author{
Priscila Primo Andrade SILVA; Flávia Maria Kazue KURITA²; Vívian TAMAKI ${ }^{3}$ \\ ${ }^{1}$ Autor para correspondência: graduada em ciências biológicas e mestre em biodiversidade vegetal e meio ambiente, Instituto \\ de Botânica da Secretaria do Meio Ambiente de São Paulo, Núcleo de Pesquisa em Plantas Ornamentais, Av. Miguel \\ Stéfano, 3687 - Água Funda, São Paulo-SP, 04301-902, pri.primo@hotmail.com. \\ ${ }^{2}$ Doutora, Instituto de Botânica da Secretaria do Meio Ambiente de São Paulo, flaviakurita@yahoo.com.br \\ ${ }^{3}$ Doutora, Instituto de Botânica da Secretaria do Meio Ambiente de São Paulo, vtamaki@gmail.com
}

Recebido em: 01-12-2016; Aceito em: 23-02-2017

\begin{abstract}
Ananas comosus var. ananassoides (Baker) Coppens \& F. Leal is a terricole ornamental bromeliad native of the Cerrado. Since this biome is threatened of extinction, studies about the cultivation of seedlings of this species are important and the in vitro culture can be a useful tool for its propagation. This work aimed to multiply $A$. comosus var. ananassoides in vitro, by means of nodal segments, and with the culture medium containing different nitrogen (N) concentrations. In obtaining the nodal segments, the plants remained in vitro in the dark for three months. In the other experiment, the seedlings were cultured in vitro in MS medium containing different $\mathrm{N}$ concentrations for six months. The results showed that $92 \%$ of the plants presented stem etiolation in the dark, each plant generating three to four nodes, and these nodes gave rise to healthy plants. Moreover, in vitro multiplication with $15 \mathrm{mM}$ and $30 \mathrm{mM} \mathrm{N}$ was found to be possible, yielding $1.5 \%$ and $3 \%$ multiplication, respectively, with each plant generating one or two buds. It is concluded that the production of plants by nodal segments is indicated for the in vitro multiplication of this species and it is suggested to culture it in $15 \mathrm{mM} \mathrm{N}$.
\end{abstract}

Additional keywords: Bromeliad; in vitro culture; multiplication; nitrogen; stem etiolation.

\begin{abstract}
Resumo
Ananas comosus var. ananassoides (Baker) Coppens \& F. Leal é uma bromélia ornamental terrícola e nativa do cerrado. Como este bioma se encontra ameaçado de extinção, estudos sobre o cultivo de mudas desta espécie são importantes, e a cultura in vitro pode ser uma ferramenta útil para sua propagação. Este trabalho teve como objetivo multiplicar in vitro $A$. comosus var. ananassoides por meio de segmentos nodais, e com meio de cultura contendo diferentes concentrações de nitrogênio $(\mathrm{N})$. Na obtenção dos segmentos nodais, as plantas permaneceram in vitro, no escuro, por três meses. No outro experimento, as plântulas foram cultivadas in vitro, em meio MS contendo diferentes concentrações de N, por seis meses. Os resultados mostraram que $92 \%$ das plantas apresentaram estiolamento caulinar no escuro, gerando de três a quatro nós cada planta, e os nós originaram plantas saudáveis. Além disso, observou-se ser possível a multiplicação in vitro com $15 \mathrm{mM}$ e $30 \mathrm{mM}$ de N, obtendo-se $1,5 \%$ e $3 \%$ de multiplicação, respectivamente, sendo que cada planta gerou de um a dois brotos. Conclui-se que a produção de plantas por segmentos nodais é indicada para a multiplicação in vitro desta espécie e sugere-se o seu cultivo em $15 \mathrm{mM}$ de $\mathrm{N}$.
\end{abstract}

Palavras-chave adicionais: Bromélia; cultivo in vitro; estiolamento caulinar; multiplicação; nitrogênio.

\section{Introduction}

Ananas comosus var. ananassoides (Baker) Coppens \& F. Leal is a terricole bromeliad used in ornamentation, having its inflorescence exported to European countries (Paula \& Silva, 2004; Carvalho et al., 2009; Souza et al., 2012). This species, popularly known as "Abacaxizinho do Cerrado", is native from Cerrado (Proença \& Sajo, 2007). As this biome is threatened with extinction, being among the 34 global biodiversity hotspots (Myers et al., 2000; Orme et al., 2005), studies and conservation measures of its spe- cies are necessary.

One way of conserving a species can be through propagation studies and the in vitro cultivation is one of the methods used for multiplication of species threatened by extinction and also for the commercial production of plants, proving to be an important tool in biotechnological research (Engelmann, 1991; Fay, 1994; Sarasan et al., 2006; Vieira et al., 2009; Carvalho et al., 2012) and in physiological studies related to plant development (Suzuki et al., 2010).

The in vitro vegetative propagation, also called micropropagation, has been an instrument used in 
several studies on the cultivation of bromeliads (Souza et al., 2009; Carvalho et al., 2012; Dias et al., 2013; Andrade \& Tamaki, 2016), whether these are of commercial interest, endemic, rare and/or threatened by extinction (Mercier \& Kerbauy, 1995; 1996; Arrabal et al., 2002; Rodrigues et al., 2004; Rech-Filho et al., 2005; Kurita, 2011; Kurita et al., 2014; Andrade \& Tamaki, 2016).

Among the micropropagation methods, it can be mentioned the multiplication by stem etiolation (Kiss et al., 1995; Tamaki et al, 2007; Santos, 2009; Dias et al., 2011) and the use of different concentrations of nitrogen (N) (Araujo et al., 2009; Kurita, 2011; Dias et al., 2013; Kurita \& Tamaki, 2014; Andrade \& Tamaki, 2016), which could be applied to the bromeliad A. comosus var. ananassoides, since there is little information available about the production of seedlings of this species and the best conditions for culturing them.

Tamaki et al. (2007) reported that the use of plant growth regulators in the production of pineapple seedlings, through nodal segments from plants cultured in vitro, subject to etiolation conditions such as lack of light, is unnecessary, as observed by Barboza \& Caldas (2001), Moreira et al. (2003) and Santos et al. (2010), suggesting that it is possible to use this method with other species.

The choice of the most suitable culture medium is fundamental for establishing the cultivation, since mineral nutrition implies the growth and development of plants (Bunn et al., 2011). Among the formulations of the culture medium described in the literature, the most used for in vitro culture is the one developed by Murashige \& Skoog (1962) (MS) (Werner et al., 2010). Some studies have reported that modifications in the MS medium, such as changes in N concentration, may favor the multiplication of some plants, as in Alcantarea imperialis (Carrière) Harms (Kurita \& Tamaki, 2014).

Maldaner et al. (2006), working with Pfaffia glomerata (Spreng.) Pedersen in vitro, observed that the reduction of the $\mathrm{N}$ concentration to $50 \%$ of the MS medium, associated with an increase in the sucrose dose to $45 \mathrm{~g} \mathrm{~L}^{-1}$, favored an increase in height, in the number of nodal segments and buds, as well as in the biomass production of $P$. glomerata. Thus, the present work aimed to evaluate the multiplication and the in vitro development of the bromeliad $A$. comosus var. ananassoides with the use of different concentrations of nitrogen and by stem etiolation.

\section{Material and methods}

\section{Plant material}

The work was carried out in the Laboratory of the Ornamental Plants Research Center, of the Institute of Botany (IBt) belonging to the Environment Secretariat of the State of São Paulo. In the experiments, seeds of Ananas comosus var. ananassoides (Baker) Coppens \& F. Leal collected in the Biological Reserve of Mogi-Guaçu, belonging to the IBt, were used. The fruits were manually opened and their seeds were packed in brown paper bags and stored under refrigeration conditions at $10^{\circ} \mathrm{C}$.

For the in vitro germination, about 650 seeds were subjected to surface disinfestation in a $250 \mathrm{~mL}$ flask containing $70 \%$ alcohol for 5 minutes, being, after rinsing, placed with $2 \%$ sodium hypochlorite solution, plus two drops of Tween 20, for one hour, under stirring. Subsequently, in a sterile air-flow chamber, the hypochlorite solution was withdrawn and the process was terminated with four consecutive washes of the seeds with sterile distilled water. After disinfestation, the seeds were deposited in Petri dishes containing only agar and $3 \%$ sucrose. The $\mathrm{pH}$ of the medium was adjusted to 5.8 before the addition of $5 \mathrm{~g} \mathrm{~L}^{-1}$ agar. Medium sterilization was performed at $120^{\circ} \mathrm{C}$ for $15 \mathrm{mi}-$ nutes. The seeds were deposited in 9-cm-diameter Petri dishes containing $20 \mathrm{~mL}$ of culture medium each, with 25 seeds per dish. These were kept in culture room with photoperiod of 12 hours, photosynthetically active radiation (PAR) of $30 \mu \mathrm{mol} \mathrm{m} \mathrm{m}^{-2} \mathrm{~s}^{-1}$ and temperature of $26 \pm 2{ }^{\circ} \mathrm{C}$ until the seedlings were obtained, which took 30 days.

\section{Multiplication by stem etiolation}

In the experiment of multiplication by stem etiolation, 100 seedlings were used, which were transferred to $350 \mathrm{~mL}$ flasks (10 seedlings per flask), containing $30 \mathrm{~mL}$ of $\mathrm{MS}$ medium with $50 \%$ of the macronutrient concentrations of the original formulation (MS/2), supplemented with $30 \mathrm{~g} \mathrm{~L}^{-1}$ of sucrose and $5 \mathrm{~g} \mathrm{~L}^{-1}$ of agar. They remained for two months under the same light conditions in culture room for germination. The generated plants had their leaves cut, leaving about $1 \mathrm{~cm}$ of leaves from the stem base, and then were transferred to $360 \mathrm{~mL}$ flasks containing $30 \mathrm{~mL}$ of $\mathrm{MS} / 2$ medium (five plants per flask). The flasks remained in the dark for three months. After this period, the plants were analyzed about the number of specimens etiolated and the number of nodes per plant. The generated nodes were transferred to $360 \mathrm{~mL}$ flasks containing $30 \mathrm{~mL}$ of $\mathrm{MS} / 2$ medium (three nodes per flask) and kept in culture room with $12 \mathrm{~h}$ photoperiod, PAR of $30 \mu \mathrm{mol} \mathrm{m}^{-2} \mathrm{~s}^{-1}$ and temperature of $26 \pm 2{ }^{\circ} \mathrm{C}$, aiming to follow the emergence of new plants for a period of three months. After this period, the generated plants were quantified.

\section{Multiplication with different concentrations of nitrogen $(\mathrm{N})$}

In the experiment of multiplication with different nitrogen $(\mathrm{N})$ concentrations, the seedlings obtained were transferred to $350 \mathrm{~mL}$ flasks, containing $30 \mathrm{~mL}$ of MS medium modified with different $\mathrm{N}$ compositions (0 mM, $7.5 \mathrm{mM}, 15 \mathrm{mM}, 30 \mathrm{mM}$, original MS - $60 \mathrm{mM}$, $120 \mathrm{mM}$ and $175 \mathrm{mM}$ ) (Table 1), supplemented with $30 \mathrm{~g} \mathrm{~L}^{-1}$ sucrose and $5 \mathrm{~g} \mathrm{~L}^{-1}$ agar. Each treatment consisted of 15 flasks and five seedlings were deposited in each flask, which were kept under aseptic conditions in 
culture room with $12 \mathrm{~h}$ photoperiod, PAR of $30 \mu \mathrm{mol} \mathrm{m} \mathrm{m}^{-2} \mathrm{~s}^{-1}$ and mean temperature of $26 \pm 2{ }^{\circ} \mathrm{C}$ for six months. Three months after the transfer initiation, they were placed in new culture medium (subcultured) with the same concentrations, to guarantee the same nutritional content due to the consumption of nutrients of the cul- ture medium by the plants. After six months, the following parameters were analyzed: number of multiplied plants; number of buds per plant; number of leaves and roots; length of shoots and roots; fresh and dry mass of shoots and roots; and quantifications of photosynthetic pigments.

Table 1 - Salts concentrations in the treatments with $0,7.5,15,30,60,120$ and $175 \mathrm{mM}$ of nitrogen $(\mathrm{N})$, changed from original Murashige \& Skoog medium (1962) (MS).

\begin{tabular}{lccccccc}
\hline \multirow{2}{*}{$\begin{array}{l}\text { Salts } \\
\left(\mathrm{g} \mathrm{L}^{-1}\right)\end{array}$} & 0 & 7.5 & 15 & 30 & $60^{*}$ & 120 & 175 \\
\cline { 2 - 8 } $\mathrm{KNO}_{3}$ & - & 0.38 & 0.38 & 0.38 & 0.38 & 0.38 & 0.38 \\
$\mathrm{NH}_{4} \mathrm{NO}_{3}$ & - & 0.15 & 0.45 & 1.05 & 2.25 & 4.65 & 6.85 \\
$\mathrm{CaCl}_{2} 2 \mathrm{H}_{2} \mathrm{O}$ & 0.44 & 0.44 & 0.44 & 0.44 & 0.44 & 0.44 & 0.44 \\
$\mathrm{MgSO}_{4} 7 \mathrm{H}_{2} \mathrm{O}$ & 0.37 & 0.37 & 0.37 & 0.37 & 0.37 & 0.37 & 0.37 \\
$\mathrm{KH}_{2} \mathrm{PO}_{4}$ & 0.17 & 0.17 & 0.17 & 0.17 & 0.17 & 0.17 & 0.17 \\
$\mathrm{KCl}$ & 0.70 & - & - & - & - & - & - \\
$\mathrm{K}_{2} \mathrm{SO}_{4}$ & 0.82 & - & - & - & - & - & - \\
\hline
\end{tabular}

* Corresponds to the concentration present in the original MS medium.

\section{Photosynthetic pigments content}

The photosynthetic pigments extraction process was based on Lichtenthaler (1987), where cold acetone and triplicate plant material previously stored at $-20{ }^{\circ} \mathrm{C}$ were used. $0.5 \mathrm{~g}$ of fresh leaf mass were ground in $3 \mathrm{~mL}$ of cold acetone. The sample was filtered through funnels previously lined with filter paper moistened with cold acetone. After the entire liquid was filtered, the filter paper was washed with acetone until the deposited material lost its green color, being collected in $25 \mathrm{~mL}$ volumetric flasks. Thereafter, pure acetone was added until completion of $25 \mathrm{~mL}$. The samples were stored on ice in test tubes and capped with aluminum foil and transparent PVC film until reading. The test tubes were removed from ice and subjected to spectrophotometry. The absorbance $(A)$ of chlorophyll $a$ was read at $661.6 \mathrm{~nm}$, chlorophyll $b$ at $644.8 \mathrm{~nm}$ and carotenoids at $470 \mathrm{~nm}$. The concentrations of chlorophyll a $(\mathrm{Ca})$, chlorophyll $b(\mathrm{Cb})$ and carotenoids $(C)$ were obtained by equations: $C a=11.24 A_{661.6}-2.04 A_{644.8} ; C b=20.13 A_{644.8}-4.19 A_{661.6} ;$ $C=\left(1000 A_{470}-1.90 \mathrm{Ca}-63.14 \mathrm{Cb}\right) 214^{-1}$. The chlorophyll and carotenoid contents of the tissues were expressed in $\mu \mathrm{g}$ of the pigment per gram of fresh leaf mass $\left(\mu g^{-1}\right)$.

\section{Statistical Analysis}

The experimental design was completely randomized and each experimental unit consisted of five flasks containing five plants and three replicates for each treatment. For the statistical analyses, the means were calculated and submitted to variance analysis, being compared by Tukey test at $5 \%$ probability.

\section{Results and discussion}

\section{Multiplication by stem etiolation}

Of the 100 plants used in the stem etiolation experiment, 92\% showed stem elongation in the absence of light, generating three to four nodes per plant in three months at in vitro culture (Table 2).

Of the 92 etiolated plants, 376 nodal segments were obtained, of which $24.2 \%$ (91 nodes) originated only a single plant, $31.7 \%$ (119 nodes) gave rise of two to six plants per nodal segment and $44.1 \%$ (166 nodes) did not develop (Table 3).

Of the nodal segments that provided more than one plant, it was obtained a total of 405 plants developed in three months of in vitro culture, in culture room, with the absence of plant growth regulators. Similarly, Santos et al. (2010), in a work on the micropropagation of the bromeliad Acanthostachys strobilacea (Schultz F.) Klotzsch cultured in MS with $1 / 5$ of the concentration of the macronutrients, verified that the middle and basal segments give rise to more than one plant per segment, without the use of plant growth regulators, as in the present work.

Tabela 2 - Distribution in nodal segments numbers per etiolated plant of Ananas comosus var. ananassoides (Baker) Coppens \& F.Leal, after three months kept in the absence of light.

\begin{tabular}{lccccccccccc}
\hline Nodal segments numbers & 00 & 01 & 02 & 03 & 04 & 05 & 06 & 07 & 10 & 11 & $\begin{array}{c}\text { Total of } \\
\text { plants }\end{array}$ \\
\hline $\begin{array}{l}\text { Number of plants that developed nodal } \\
\text { segments }\end{array}$ & 08 & 01 & 04 & 33 & 27 & 19 & 03 & 02 & 01 & 02 & 100 \\
\hline
\end{tabular}


Table 3 - Nodal segments number of Ananas comosus var. ananassoides (Baker) \& Coppens F. Leal which developed one plant, more than one plant per segment, and not developed, with the respective percentages, after six months of in vitro culture.

\begin{tabular}{lrccc}
\hline & $\begin{array}{c}\text { Developed a } \\
\text { plant }\end{array}$ & $\begin{array}{c}\text { Developed more than one } \\
\text { plant }(2-6)\end{array}$ & $\begin{array}{c}\text { Have not developed } \\
\text { a plant }\end{array}$ & $\begin{array}{c}\text { Total of } \\
\text { segments } \\
\text { obtained }\end{array}$ \\
\hline Nodal segments numbers & 91 & 119 & 166 & 376 \\
Relative frequency $(\%)$ & 24.7 & 31.7 & 44.1 & 100 \\
\hline
\end{tabular}

Kiss et al. (1995) propagated nodal segments of Ananas comosus (L.) Merril, cultivar Smooth Cayenne, in vitro with two types of cytokinins (benzyladenine-BA and kinetin- $K$ ) with different concentrations $(0 \leq \mathrm{BA} \leq 40 \mu \mathrm{m}$ and $0 \leq \mathrm{K} \leq 50 \mu \mathrm{m})$ in N6 culture medium (Chu, 1978), verifying that it is possible to use this method for the micropropagation of this species. However, Tamaki et al. (2007) reported that the use of plant growth regulators in the production of seedlings of this same species by stem etiolation is unnecessary, as observed in the present study for $A$. comosus var. ananassoides.

In many studies, the use of plant growth regulators is associated with the induction of somaclonal variations in plant tissues (Pierik, 1987; Zaffari et al., 2002; Joyce et al., 2003; Zhao et al., 2005). These changes are not relevant when it is sought to obtain plants with selected phenotypes (Tamaki et al., 2007) or when the aim is the conservation of a species.

In relation to the total yield of plants obtained from the stem etiolation method used in the present study, around four new plants were obtained from a matrix plant, in six months of in vitro culture in MS/2 medium. Santos et al. (2010) obtained superior results in their work with $A$. strobilacea, about 80 plants from a matrix plant, in a year of in vitro and ex vitro culture. With these results, there is a need for further studies to improve the technique with $A$. comosus var. ananassoides, aiming to increase the amount of individuals generated by the matrix plant, without the use of growth regulators.

Thus, the possible production of seedlings verified in A. comosus var. ananassoides may serve for future physiological research, in addition to contributing to the propagation and conservation of this species.

\section{Multiplication with different concentrations of nitrogen}

In the experiment of multiplication with different concentrations of $\mathrm{N}$, all plants survived at the concentration changes of $0 \mathrm{mM}, 7.5 \mathrm{mM}, 15 \mathrm{mM}, 30 \mathrm{mM}$, $60 \mathrm{mM}, 120 \mathrm{mM}$ and $175 \mathrm{mM} \mathrm{N}$ in the nutrient media for six months, but the multiplication was only observed in two concentrations, with the appearance of a bud in a plant at the concentration of $15 \mathrm{mM} \mathrm{N}$ and two buds in two plants at the concentration of $30 \mathrm{mM} \mathrm{N}$; in the other concentrations, there were no buds. However, Maldaner et al. (2006), studying the in vitro growth of Pfaffia glomerata (Spreng.) Pedersen at different $\mathrm{N}$ concentrations, reported that the reduction of $\mathrm{N}$ to $50 \%$ of that MS medium standard, associated with an increase in the sucrose dose to $45 \mathrm{~g} \mathrm{~L}^{-1}$, favored the emergence of buds, as well as the production of biomass. The same was observed by Kurita \& Tamaki (2014), working with the bromeliad Alcantarea imperialis (Carrière) Harms with different $\mathrm{N}$ concentrations $(0 \leq N \geq 175 \mathrm{mM})$, where $80 \%$ of the plants grown at the concentration of $30 \mathrm{mM} \mathrm{N}$ generated from two to five buds per plant. Nonetheless, the change in the $\mathrm{N}$ concentration in the MS culture medium, alone, was not sufficient to generate buds in plants of Ananas comosus var. ananassoides.

Regarding the shoot growth data of the plants grown at different concentrations of $\mathrm{N}$ for six months, in general, the lowest avareges were observed only in the treatment with $0 \mathrm{mM} \mathrm{N}$ (Table 4). There was a difference in the amount of leaves between the treatments used, about eight leaves at the $0 \mathrm{mM} \mathrm{N}$ concentration, nine leaves at the $15 \mathrm{mM} \mathrm{N}$ concentration and approximately 10 leaves at the concentrations of $7.5 \mathrm{mM}, 30 \mathrm{mM}, 60 \mathrm{MM}, 120 \mathrm{mM}$ and $175 \mathrm{mM} \mathrm{N}$ (Table 4). This variation in the number of leaves was also observed by Kanashiro (2005), in his work with the bromeliad Aechmea blanchetiana (Baker) L.B. Smith., when analyzing its in vitro growth at different concentrations of nitrogen $(7.5 \leq \mathrm{N} \geq 120 \mathrm{mM})$. The same author also verified that the increase of the nitrogen concentration induced the increase of the amount of leaves, as it seems to have occurred with $A$. comosus var. ananassoides in the present study.

Regarding shoot length (Table 4), the smaller leaves were obtained in the plants at the concentrations of $0 \mathrm{mM}(5.40 \pm 0.70 \mathrm{~cm})$ and $175 \mathrm{mM} \mathrm{N}$ $(6.67 \pm 1.01 \mathrm{~cm})$; the other treatments presented plants with an average of $7.81 \mathrm{~cm}$ shoot length. Grossi (2000), when culturing in vitro the bromeliad Aechmea nudicaulis (L.) Griseb. at the concentrations of 1.78, 7.5 and $30 \mathrm{mM} \mathrm{N}$ of the MS, found that this species presented a higher increase in shoot length at the concentration of $7.5 \mathrm{mM} \mathrm{N}$ after 5 months of cultivation. Notwithstanding, Russowski \& Nicoloso (2003) analyzed the effect of different concentrations of nitrogen $(0 \leq N \leq 150 \%)$ of the MS medium on nodal segments of Pfaffia glomerata (Spreng.) Pedersen (Brazilian Ginseng) and observed that after 15 days, the shoot height was higher in $100 \% \mathrm{~N}(60 \mathrm{mM} \mathrm{N})$, with a decrease in length at higher concentrations. In $A$. comosus var. ananassoides, there also seems to be a tendency to reduce leaf length at concentrations above $60 \mathrm{mM} \mathrm{N}$ (Table 4). 
Table 4 - Average values of fresh and dry weight of the shoot, length of the largest leaf and leaves number in Ananas comosus var. ananassoides (Baker) F. Leal \& Coppens plant, after six months of in vitro culture in the nitrogen (N) concentrations of $7.5 \mathrm{mM}, 15 \mathrm{mM}, 30 \mathrm{mM}, 60 \mathrm{mM}, 120 \mathrm{mM}$ and $175 \mathrm{mM}$.

\begin{tabular}{|c|c|c|c|c|}
\hline $\begin{array}{l}\text { Treatments } \\
(\mathrm{mM} \text { of } \mathrm{N})\end{array}$ & 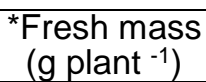 & $\begin{array}{l}\text { *Dry mass } \\
\left(\mathrm{g} \mathrm{plant}^{-1}\right)\end{array}$ & $\begin{array}{l}\text { *Length of the largest leaf } \\
(\mathrm{cm})\end{array}$ & $\begin{array}{l}{ }^{*} \text { Number of } \\
\text { leaves }\end{array}$ \\
\hline 0 & $0.2903 \mathrm{~b}$ & $0.0344 \mathrm{~b}$ & $5.40 \mathrm{c}$ & $08.4 \mathrm{c}$ \\
\hline 7.5 & $0.6137 a$ & $0.0590 \mathrm{a}$ & $7.56 \mathrm{ab}$ & $10.6 \mathrm{ab}$ \\
\hline 15 & $0.7005 a$ & $0.0707 \mathrm{a}$ & $8.30 \mathrm{a}$ & $09.7 \mathrm{~b}$ \\
\hline 30 & $0.5770 a$ & $0.0605 a$ & $8.33 a$ & $10.4 \mathrm{ab}$ \\
\hline 60 & $0.6533 a$ & $0.0681 \mathrm{a}$ & $8.20 \mathrm{a}$ & $09.9 \mathrm{ab}$ \\
\hline 120 & $0.6065 a$ & $0.0629 a$ & $7.74 \mathrm{ab}$ & $09.9 \mathrm{ab}$ \\
\hline 175 & $0.5414 \mathrm{a}$ & $0.0483 \mathrm{a}$ & $6.67 \mathrm{~b}$ & $10.9 \mathrm{a}$ \\
\hline
\end{tabular}

${ }^{*}$ Means followed by the same letter in the column do not differ by Tukey test at $5 \%$ probability.

In relation to the results of fresh mass of shoots, there were no significant differences in the plants grown with $7.5 \mathrm{mM} \mathrm{N}$ up to $175 \mathrm{mM} \mathrm{N}$, and the highest average was observed at $15 \mathrm{mM} \mathrm{N}(0.70 \pm 0.11 \mathrm{~g})$ (Table 4). The dry mass of shoots was higher in the treatments from $15 \mathrm{mM} \mathrm{N}$ to $175 \mathrm{mM} \mathrm{N}$, and at 15 and $60 \mathrm{mM} \mathrm{N}$, the plants obtained the highest averages $(0.07 \pm 0.01 \mathrm{~g}$ and $0.068 \pm 0.017 \mathrm{~g}$, respectively) (Table 4). The plants cultured in the absence of $\mathrm{N}$ did not present mortality, but obtained the lowest averages of fresh mass and dry mass $(0.29 \pm 0.07 \mathrm{~g}$ and $0.031 \pm$ $\pm 0.006 \mathrm{~g}$, respectively). When studying the growth of the bromeliad A. blanchetiana, cultured in vitro for 120 days at different concentrations of nitrogen $(7.5 \leq \mathrm{N} \geq 120 \mathrm{mM})$, Kanashiro et al. (2007) observed that the increase of nitrogen concentration reduced the fresh and dry mass of shoots, a result opposite to that observed in $A$. comosus var. ananassoides. Dijik \& Eck (1995) studied the in vitro growth of three species of orchids (of the same genus and habit) for five months and observed different behaviors among the specimens when they increased the concentration of nitrogen in the nutrient medium (from 0 to $12 \mathrm{mM} \mathrm{N}$ ), with increased biomass production in Dactylorhiza praetermissa (Druce) Soó, while D. majalis (Rchb. F.) P.F. Hunt \& Summerh remained stable and $D$. incarnata (L.) Soó showed biomass reduction. Thus, it can be concluded that different species, although belonging to the same genus and habit, may present different responses in relation to the increase in nitrogen fertilization.

As for the results of photosynthetic pigments, there was no significant difference between the $7.5 \mathrm{mM}, 15 \mathrm{mM}, 30 \mathrm{mM}$ and $60 \mathrm{mM} \mathrm{N}$ treatments, however, there was a decline in the treatments with $0 \mathrm{mM}, 120 \mathrm{mM}$ and $175 \mathrm{mM} \mathrm{N}$ (Table 5). Tamaki et al. (2007) cultured $A$. comosus plants, from nodal segments of the etiolated stem axis in the absence of light, at different macronutrient dilutions of the MS medium (60 mM N - MS; $30 \mathrm{mM} \mathrm{N}-\mathrm{MS} \mathrm{2}^{-1} ; 12 \mathrm{mM} \mathrm{N}$ - MS 5-1; $6 \mathrm{mM} \mathrm{N}$ - MS 10-1; $1 \mathrm{mM} \mathrm{N}-\mathrm{MS} \mathrm{60}^{-1}$; and $0.6 \mathrm{mM} \mathrm{N}-\mathrm{MS} 100^{-1}$ ) for 90 days, and observed that there were no significant differences between treatments: MS, MS $2^{-1}$ and MS $5^{-1}$, showing that the amount of $\mathrm{N}$ in MS $5^{-1}$ was sufficient for the normal development of the plant, a result similar to that observed in the bromeliad under study, A. comosus var. ananassoides.

Table 5 - Average values of photosynthetic pigments (chlorophylls $a, b$ and carotenoids) in Ananas comosus var. ananasssoides (Baker) F. Leal \& Coppens leaves, after six months of in vitro culture in the nitrogen $(\mathrm{N})$ concentrations of $7.5 \mathrm{mM}, 15 \mathrm{mM}, 30 \mathrm{mM}, 60 \mathrm{mM}, 120 \mathrm{mM}$ and $175 \mathrm{mM}$.

\begin{tabular}{cccc}
\hline $\begin{array}{c}\text { Treatments } \\
(\mathrm{mM} \text { of } \mathrm{N})\end{array}$ & $\begin{array}{c}{ }^{*} \text { Chlorophyll a } \\
\left(\mu \mathrm{g} \mathrm{g}^{-1} \text { fresh mass }\right)\end{array}$ & $\begin{array}{c}{ }^{*} \text { Chlorophyll b } \\
\left(\mu \mathrm{g} \mathrm{g}{ }^{-1} \text { dry mass }\right)\end{array}$ & $\begin{array}{c}{ }^{*} \text { Carotenoids } \\
\left(\mu \mathrm{g} \mathrm{g}^{-1} \text { fresh mass }\right)\end{array}$ \\
\hline 0 & $366.4 \mathrm{~d}$ & $158.7 \mathrm{c}$ & $99.0 \mathrm{~b}$ \\
7.5 & $894.2 \mathrm{ab}$ & $376.1 \mathrm{a}$ & $216.8 \mathrm{a}$ \\
15 & $911.2 \mathrm{ab}$ & $386.9 \mathrm{a}$ & $209.5 \mathrm{a}$ \\
30 & $858.3 \mathrm{ab}$ & $372.0 \mathrm{a}$ & $201.6 \mathrm{a}$ \\
60 & $1002.9 \mathrm{a}$ & $446.7 \mathrm{a}$ & $230.8 \mathrm{a}$ \\
120 & $802.9 \mathrm{~b}$ & $354.3 \mathrm{ab}$ & $194.6 \mathrm{a}$ \\
175 & $583.0 \mathrm{c}$ & $265.4 \mathrm{~b}$ & $142.9 \mathrm{~b}$ \\
\hline
\end{tabular}

* Means followed by the same letter in the column do not differ by Tukey test at $5 \%$ probability.

Regarding the variable root length, the lowest results were obtained at the concentrations of $120 \mathrm{mM}$ $\mathrm{N}(2.75 \pm 0.59 \mathrm{~cm})$ and $175 \mathrm{mM} \mathrm{N}(1.82 \pm 0.70 \mathrm{~cm})$ and the highest result was found at the concentration of $7.5 \mathrm{mM} \mathrm{N}(8.94 \pm 2.13 \mathrm{~cm})$; the remaining treatments presented plants with a mean of $4.32 \mathrm{~cm}$ root length (Table 6). Garnetti et al. (2009), in their review work about $\mathrm{N}$ and its effects on roots, reported a reduction in root growth at high concentrations of $\mathrm{N}$, as observed in this work. Possibly, such reduction of growth in the treatments of $120 \mathrm{mM}$ and $175 \mathrm{mM} \mathrm{N}$ occurs by a certain degree of toxicity when subjected to these high concentrations. According to Marschners and Marschners (2012), minerals excess in the soil makes it saline, causing little availability of water, inducing the plant to saline and water stress, and with that, there is growth reduction. 
Table 6 - Average values of fresh and dry weigth of the root and length in the largest root in Ananas comosus var. ananassoides (Baker) F. Leal \& Coppens plant, after six months of in vitro culture in the nitrogen $(\mathrm{N})$ concentrations of $0 \mathrm{mM}, 7.5 \mathrm{mM}, 15 \mathrm{mM}, 30 \mathrm{mM}, 60 \mathrm{mM}, 120 \mathrm{mM}$ and $175 \mathrm{mM}$.

\begin{tabular}{cccc}
\hline $\begin{array}{c}\text { Treatments } \\
(\mathrm{mM} \text { of N })\end{array}$ & $\begin{array}{c}\text { *Fresh mass } \\
\left(\mathrm{g} \mathrm{plant}^{-1}\right)\end{array}$ & $\begin{array}{c}\text { "Dry mass } \\
\left(\mathrm{g} \mathrm{plant}^{-1}\right)\end{array}$ & $\begin{array}{c}\text { *Length of the largest root } \\
(\mathrm{cm})\end{array}$ \\
\hline 0 & $0.0190 \mathrm{c}$ & $0.0078 \mathrm{~b}$ & $4.80 \mathrm{~b}$ \\
7.5 & $0.0417 \mathrm{ab}$ & $0.0119 \mathrm{a}$ & $8.94 \mathrm{a}$ \\
15 & $0.0291 \mathrm{~b}$ & $0.0066 \mathrm{~b}$ & $4.30 \mathrm{~b}$ \\
60 & $0.0317 \mathrm{~b}$ & $0.0057 \mathrm{~b}$ & $4.00 \mathrm{~b}$ \\
10 & $0.0502 \mathrm{a}$ & $0.0080 \mathrm{~b}$ & $4.20 \mathrm{~b}$ \\
175 & $0.0293 \mathrm{~b}$ & $0.0047 \mathrm{bc}$ & $2.75 \mathrm{c}$ \\
\hline
\end{tabular}

${ }^{*}$ Means followed by the same letter in the column do not differ by Tukey test at $5 \%$ probability.

The root growth was shown to be higher when there was low $\mathrm{N}$ availability, as seen by Kurita \& Tamaki (2014) when studying the in vitro culture of the bromeliad Alcantarea imperialis at different concentrations of N. In their study, it was verified that this species of bromeliad presented greater root growth in the treatment with $7.5 \mathrm{mM} \mathrm{N}(5.80 \pm 0.87 \mathrm{~cm})$, a result similar to that of $A$. comosus var. ananassoides.

Working with the bromeliad $A$. comosus cultured in vitro in the absence of N, Tamaki \& Mercier (2007) studied the signaling between shoots and roots, observing an accumulation of indolylacetic acid in the roots, indicating that this hormone may be signaling the lack of $\mathrm{N}$ from the leaves to the roots. According to Davies (2010), one of the hormones responsible for cell elongation is the auxin, the roots being more sensitive to this hormone, inducing root elongation at low concentrations of $\mathrm{N}$, that is, $\mathrm{N}$ deficiency leads the auxin to provide the signal that induces root growth, which may have occurred with $A$. comosus var. ananassoides at low concentrations of $\mathrm{N}$.

As for the results of fresh and dry mass of roots, plants grown at the concentrations of $7.5 \mathrm{mM}$ and $60 \mathrm{mM} \mathrm{N}$ had the highest mean values $(0.04 \pm 0.01 \mathrm{~g})$ fresh mass; $0.011 \pm 0.004 \mathrm{~g}$ dry mass and $0.05 \pm 0.01 \mathrm{~g}$ fresh mass; $0.008 \pm 0.0014 \mathrm{~g}$ dry mass, respectively) when compared to the other concentrations, and the lowest biomass was presented in plants grown at $175 \mathrm{mM}$ $\mathrm{N}(0.015 \pm 0.002 \mathrm{~g}$ fresh mass and $0.0022 \pm 0.0009 \mathrm{~g}$ dry mass (Table 6). Russowski and Nicoloso (2003), working with in vitro culture of nodal segments of $P$. glomerata at different concentrations of nitrogen $(0 \leq \mathrm{N} \leq 150 \%)$ in the MS medium $(100 \%$ with $60 \mathrm{mM} \mathrm{N})$, observed that the concentration of $80 \%$ showed plants with higher dry mass of shoots and roots, occurring a decrease as a function of the increase of N. Possibly, the smaller amount of nitrogen in the treatment of $7.5 \mathrm{mM} \mathrm{N}$ favored the increase of the dry mass in the present work, since, according to Van Der Werf (1996), the biomass allocation to the roots and shoots is deeply influenced by the availability of $\mathrm{N}$, so the reduction in $\mathrm{N}$ supply initially induces root growth and reduces shoot growth.

According to Benzing (2000), many native bromeliads are adapted to nutrient-deficient environments, what may be assumed to be the case of $A$. comosus var. ananassoides, which is a species native from Cerrado, a biome that has a soil poor in nutrients, as the results indicate that at the concentrations of 15 to $60 \mathrm{mM} \mathrm{N}$, the in vitro growth was satisfactory. Therefore, the use of $15 \mathrm{mM} \mathrm{N}$ for the cultivation of this species could reduce the use of $\mathrm{N}$ in the culture medium and consequently the costs for its production.

Thus, it is concluded that it is possible to multiply $A$. comosus var. ananassoides by in vitro culture in MS medium modified with $15 \mathrm{mM}$ and $30 \mathrm{mM}$ nitrogen, but mainly by stem etiolation in MS/2 medium. This latter method is suggested for the in vitro multiplication of this bromeliad, in addition to its in vitro culture at the $15 \mathrm{mM} \mathrm{N}$ concentration of the MS medium formulation.

\section{Acknowledgements}

To the National Council for Scientific and Technological Development (CNPq), for granting Priscila Primo Andrade Silva the financial support to the research through an individual scholarship of Initiation to Research of the Institutional Program of Scientific Initiation Scholarships - PIBIC.

\section{References}

Andrade SV, Tamaki V (2016) In vitro growth of Nidularium Minutum Mez (Bromeliaceae) in different concentrations of nitrogen, phosphorus, potassium, and calcium. Journal of Plant Nutrition 39(11)16341643.

Arrabal R, Amancio F, Carneiro LA, Neves LJ, Mansur E (2002) Micropropagation of endangered endemic Brazilian bromeliad Cryptanthus sinuosus (L. B. Smith) for in vitro preservation. Biodiversity and Conservation 11(6):1081-1089.

Araujo AG, Rodrigues MPFA, Carvalho JG, Zarraga DZA (2009) Fontes de nitrogênio no crescimento in vitro de plântulas de Cattleya loddigesii Lindl. (Orchidaceae). Acta Scientiarum. Biological Sciences 31(1): 35-39.

Barboza SBSC, Caldas LS (2001) Estiolamento e regeneração na multiplicação in vitro do abacaxizeiro hibrido PE $x$ SC-52(1). Pesquisa Agropecuária Brasileira 36(3):417-423. 
Benzing DH (2000) Bromeliaceae: profile of na adptative radiation. Cambridge University Press. 710 p.

Bunn E, Turner SR, Dixon KW (2011) Biotechnology for saving rare and threatened florain a biodiversity hotspot. In Vitro Cellular \& Developmental Biology Plant 47(1):188-200.

Carvalho ACPP, Pinheiro MVM, Dias GMG, Morais JPS (2009) Multiplicação in vitro de abacaxi ornamental por estiolamento e regeneração de brotações. Horticultura Brasileira 27(1):103-108.

Carvalho ACPP, Pinheiro MVM, Dias GMG, Morais JPS (2012) Estiolamento in vitro de plantas: alternativa para a produção de mudas micropropagadas de abacaxizeiro ornamental. Embrapa Agroindústria Tropical. $12 \mathrm{p}$.

Chu CC (1978) The N6 medium and its application to another culture of cereal crops (in Chinese) Peking: Science Press 50p.

Davies PJ (2010) The plant hormones: their nature, occurrence, and functions. Martinus Nijhoff Publishers. $801 \mathrm{p}$.

Dias MM, Pasqual M, Araujo AG, Santos VA, Oliveira AC, Rodrigues VA (2011) Concentrações de reguladores vegetais no estiolamento in vitro de ananás do campo. Semina: Ciências Agrárias 32(2):513-520.

Dias MM, Neitsche S, Pereira MCT (2013) Concentrações de NPK no cultivo in vitro de abacaxizeiro ornamental. Tecnologia \& Ciência Agropecuária 7(4):1-6.

Dijik E, Eck N (1995) Axenic in vitro nitrogen and phosphorus responses of some dutch marsh orchids. The New Phytologist 131(3):353-359.

Engelmann $F$ (1991) In vitro conservation of tropical plant germplasm: a review. Euphytica 57(1):227-243.

Fay MF (1994) In what situations is in vitro culture appropriate to plant conservation? Biodiversity and Conservation 3(2):176-183.

Garnetti T, Conn V, Kaiser B (2009) Root based approaches to improving nitrogen use efficiency in plants. Plant, Cell and Environment 32(9):1272-1283.

Grossi $F$ (2000) Aspectos da nutrição nitrogenada in vitro e atividade da redutase de nitrato em uma espécie de bromélia. Universidade de São Paulo (Tese de doutorado em Agricultura).

Joyce SM, Cassells AC, Jain M (2003) Stress and aberrant phenotypes in in vitro culture. Plant Cell, Tissue and Organ Culture74(2):103-121.

Kanashiro S (2005) Nitrogênio, fósforo, potássio e cálcio e o crescimento de plântulas de Aechemea blanchetiana (Baker) L.B. Smith in vitro. Universidade de São Paulo (Tese de doutorado em Fitotecnia).
Kanashiro S, Ribeiro RCS, Gonçalves AN, Dias CTS, Jocys $T$ (2007) Efeitos de diferentes concentrações de nitrogênio no crescimento de Aechmea blanchetiana (Baker) LB Sm. cultivadas in vitro. Hoehnea 34(1):59-66.

Kiss E, Kiss J, Gyulai G, Heszky LE (1995) A novel method for rapid micropropagation of pineapple. HortScience 30(1):127-129.

Kurita FMK (2011) Crescimento in vitro da bromélia Alcantarea imperialis (Carrière) Harms com diferentes concentrações de nitrogênio, fósforo, potássio e cálcio. Instituto de Botânica (Dissertação de mestrado em Biodiversidade Vegetal e Meio Ambiente).

Kurita FMK, Machado BM, Teixeira NB, César CGA, Nievola CC, Tamaki V (2014) Fenologia, cultivo in vitro e aclimatização da bromélia ameaçada de extinção Nidularium minutum Mez. Biotemas 27(1):59-69.

Kurita FMK, Tamaki, V (2014) In vitro growth of bromeliad Alcantarea imperialis with different concentrations of nitrogen. Acta Scientiarum. Biological Science. 36(3):279-285.

Lichtenthaler HK (1987) Chlorophylls and Carotenoids: pigments of photosynthetic biomembranes. Methods in Enzymology 148(1):350-382.

Maldaner J, Nicoloso FT, Santos ES, Flores R, Skrebsky EC (2006) Sacarose e nitrogênio na multiplicação in vitro de Pfaffia glomerata (Spreng.) Pedersen. Ciência Rural 36(4):1201-1206.

Marschner H, Marschner P (2012) Marschner's mineral nutrition of higher plants. 3 ed. Academic Press. 672p.

Mercier H, Kerbauy GB (1995) The Importance of tissue culture technique for conservation of endangered Brazilian bromeliads from Atlantic rain forest canopy. Selbyana 16(2):147-149.

Mercier H, Kerbauy GB (1996) Micropropagation of ornamental bromeliads (Bromeliaceae). In: Bajaj YPS (ed) Biotecchnology in agriculture and forestry, hightech and micropropagation, vol. 6. Springer-Verlag. p. 43-57.

Moreira MA, Pasqual M, Carvalho JG, Fráguas CB (2003) Estiolamento na micropropagação do abacaxizeiro CV. Perola. Ciência Agrotecnica, 27(5):10021006.

Murashige T, Skoog F (1962) A revised medium for rapid growth and bio assays with tobacco tissue cultures. Physiologia Plantarum 15(3):473-497.

Myers N, Mittermeier RA, Mittermeier CG, Fonseca GAB, Kent J (2000) Biodiversity hotspots for conservation priorities. Nature 403(1):853-858. 
Orme CDR, Davies RG, Burges M, Eigenbrod $F$, Pickup N, Olson VA, Webster AJ, Ding TS, Rasmussen PC, Ridgely RS, Stattersfield AJ, Bennett PM, Blackburn TM, Gaston KJ, Owens IPF (2005) Global hotspots of species richness are not congruent with endemism or threat. Nature 436(7053):1016-1019.

Paula CC, Silva HMP (2004) Cultivo prático de bromélias. UFV. 106p.

Pierik RLM (1987) In vitro culture of higher plants. Amsterdam: Kluwer Academic Publishers. 348p.

Proença SL, Sajo, MG (2007) Anatomia foliar de bromélias ocorrentes em áreas de cerrado do Estado de São Paulo, Brasil. Acta Botanica Brasílica 21(3):657673.

Rech-Filho A, Dal Vesco LL, Nodari RO, Lischka RW, Muller CV, Guerra MP (2005) Tissue culture for the conservation and mass propagation of Vriesea reitzii Leme and Costa, a bromeliad threatened of extinction from the Brazilian Atlantic Forest. Biodiversity e Conservation 14(1):1799-1808.

Rodrigues TM, Paiva PDO, Rodrigues CR, Carvalho JG, Ferreira CA, Paiva R (2004) Desenvolvimento de muda de bromelia-imperial (Alcantarea imperialis) em diferentes substratos. Ciência e Agrotecnologia 28(4):757-763.

Russowski D, Nicolosso FT (2003) Nitrogênio e fósforo no crescimento de plantas de ginseng brasileiro (Pfaffia glomerata (Spreng.) Pedersen) cultivadas in vitro. Ciência Rural 33(1):57-63.

Santos DS (2009) Micropropagação da bromélia ornamental Acanthostachys strobilacea (Schultz F.) Klotzsch e a influência do etileno. Instituto de Botânica (Dissertação de mestrado em Biodiversidade Vegetal e Meio Ambiente).

Santos DS, Tamaki V, Nievola CC (2010) In vitro propagation of the ornamental bromeliad Acanthostachys strobilacea (Schult. f.) Klotzsch via nodal segments. In Vitro Cellular \& Developmental Biology-Plant 46(6):524-529.

Sarasan V, Cripps R, Ramsay MM, Atherton C, Mcmichen M, Prendergast G, Rowntree JK (2006) Conservation in vitro of threatened plants: progress in the past decade. In vitro Cellular \& Developmental Biology Plant 42(1):206-214.
Souza FVD, Souza AS, Santos-Serejo JA, Souza EH, Junghas TG, Silva MJ (2009) Micropropagação do abacaxizeiro e outras bromeliáceas. In: Junghas TG, Souza AS (ed). Aspectos práticos da micropropagação de plantas. vol. 1. Embrapa Mandioca e Fruticultura Tropical. p. 177-205.

Souza FVD, Carvalho ACPP, Souza EH (2012) O abacaxi ornamental. In: Paiva PDO, Almeida EFAC (ed) Produção de flores de corte. UFLA. p. 18-39.

Suzuki RM, Almeida V, Pescador R, Ferreira WM (2010) Germinação e crescimento in vitro de Cattleya bicolor Lindley (Orchidaceae). Hoehnea 37(4):731742.

Tamaki V, Mercier H, Nievola CC (2007) Cultivo in vitro de clones de Ananas comosus (L.) Merril cultivar Smooth Cayene em diferentes concentrações de macronutrientes. Hoehnea 34(1):67-73.

Tamaki V, Mercier H (2007) Cytokinins and auxin communicate nitrogen availability as long-distance signal molecules in pineapple (Ananas comosus). Journal of Plant Physiology 164(11):1543-1547.

Werner ET, Milanez CRD, Mengarda LHG, Vendrame WA, Cuzzuol GRF (2010) Meios de cultura, reguladores de crescimento e fontes de nitrogênio na regulação da calogênese do pau-brasil (Caesalpinia echinata Lam.) Acta Botanica Brasilica 24(4):1046-1051.

Van Der Werf A (1996) Growth analysis and photoassimilate partioning. In: Zmski E, Schaffer AA (ed) Photoassimilate distribution in plants and crops: sourcesink relationships. Marcel Dekker, Inc. p.1-20.

Vieira JGZ, Unemoto LK, Yamakami JK, Nagashima GT, Faria RT, Aguia RRS (2009) Propagação in vitro e aclimatização de um híbrido de Cattleya Lindl. (Orchidaceae) utilizando polpa de banana e água de coco. Científica 37(1):48-52.

Zaffari GR, Peres LEP, Tcacenco FA, Kerbauy GB (2002) Indole-3- acetic acid metabolism in normal and dwarf micropropagated banana plants (Musa spp. AAA). Brazilian Journal of Plant Physiology 14(1):211217.

Zhao Y, Grout BWW, Roberts AV (2005) Abnormal chromosomes and DNA content in micropropagated rhubarb (Rheum rhaponticum L.) PC49. Plant Cell, Tissue and Organ Culture 83(3):335-338. 